\title{
The Role of Language Policy in Nation-Building in Pakistan
}

\author{
Author: \\ Hajra Yousif Pardesi \\ English language development center, \\ Mehran University of Engineering and Technology, Jamshoro, Sindh, Pakistan. \\ Co-author: \\ Dr Ambreen Shahriar \\ Associate professor \\ Institute of English language and literature, University of Sindh, Jamshoro, Sindh, Pakistan.
}

\begin{abstract}
This article presents the analysis of the relation between language policy formation and nation-identity development process in context of Pakistan. Language is not only an instrument of communication, but it is also central element of culture, resultantly reaffirming the cultural differences in contrast to other cultures. After independence, a shared common language is often used by nations as symbolic marker in order to integrate their diverse population into a single unified nation. Language become a central factor in the process of nationalism or nation-building and to culture in general, results into politicization of language policy and planning process. This paper analyzed the language policy documents of last 20 years and highlighted that in Pakistan LPP, particularly status planning, decisions are largely influenced by power politics in the country. This paper argue that the issue of language cannot be detached from the political issue of the country. Pakistan is a home to a vast number of ethnic communities, who speaks different languages. Pakistan's recognition of Urdu as national language results in given privileged status to the people who identify themselves with this language. The ruling elite enjoy the privileged status of English and Urdu language in various power domains whereas the languages of minority powerless groups are marginalized from the domains of literacy, administration, education and power. The monolingual conception of national identity has largely alienated the under-represented or powerless languages which put their native speakers at grave disadvantage. This paper proposed that language policy makers must incorporates all the indigenous language on stage in context of nation-identity development with an ideology that all language are equal linguistically or socially. Every individual has right to use and promote their mother tongue and education being basic right of every individual it should be given in one's own mother tongue.
\end{abstract}

Keywords: Nation-identity, nationalism, Language policy, Urdu language, National language, Status planning, Politics.

DOI: $10.7176 / \mathrm{JLLL} / 74-04$

Publication date: December $31^{\text {st }} 2020$

\section{Introduction}

Generally, the concept of Language is perceived as a mere medium to covey meaning by the population in a speech community in order to practice social lives. As Spolsky (2004) assert linguistic ecologies equalized with the contextualized practical usage of linguistic units. But language is much more than this simpler definition. The sign system dimension of language view makes it as capable of conveying the meanings semantically, in addition to the cultural and social values it carries with and within itself (Kramsch, 2009). Language being associated with culture and history of a community; it is centrally being used by the people to identify themselves within their community and against the people belonging other communities through the social interaction in that language. As Kramsch $(2009$, p.3) stated that, "people view their language as a symbol of their social identity". Tong \& Cheung (2011) even asserted that language reflects the lifestyle as well as being the carrier of social and cultural identities of their native speakers residing in a particular geographical region. In this sense, in order to construct national identities and promote nationalism, it is important to resort the use of a common language to integrate a population into a nation within a state. Language is a useful tool to bind individuals into a single community with common identity, as it is being an important symbolic marker of an individual's or a group's identity (Kaur \& Shapii, 2018, p.2). Such effort become a compulsion in states with multiethnic, multicultural and multilingual contexts, for instance; India, Pakistan and Ethiopia. The process of language policy and planning are crucial for newly independent nation states, like Pakistan, in order to adopt a national and official language to assist the development of a nation-state and socio-economic equality within its population.

The linguistic laws and policies in Pakistan have experienced numerous shifts in history mainly due to the political agendas it incorporates. According to Whitley (1983), the language policy decisions are often determined on 'political grounds and always follow certain ideologies. It is not merely based on linguistic issue on which it should be following, so the language policy planning needs to be viewed from political perspective (Rahman, 2007, 
2010; Manan et al., 2017; Mustafa, 2011). Since the inception of Pakistan, Urdu was represented as its national language and English is regarded as official language of the state (Shah \& Pathan, 2016; Pathan, 2012). The privilege position of these languages seems to be under attack with the presence of ethno-nationalist who regard their language as crucial heritage to them, who criticize state's policies as discriminatory and hegemonic. The psychological dimension of such policy allows only one or two cultures to prevail and dominate over the entire multicultural population, which eventually would never receive any positive incorporation into the dominant culture and social system. Language cannot be separated from culture. As Jaspel (2009) narrated that language primarily perform two main goals: communication and construction of one's social identity (cited in Shah, et al. 2018). Errington (2008) emphasized that languages have deeper connection with its speakers and their residing lands. All the human teaching and knowledge are preserved in their language, in case if their language is lost, then their culture, intellectual, philosophical, spiritual and unique way of perceiving world is also lost. So, the dominance of one culture is not tolerable for ethno-nationalists who view it as marginalization of indigenous people's cultures and languages, which is termed as 'genocide' by Skutnabb-Kangas cited in Phillipson, 1992). Therefore, the current study aims to show that how language may also be used as a political and social tool in a society. It investigates the role language play in the process of the construction and maintenance of unified nation and its national identity, and their consequences on indigenous languages in Pakistan. Furthermore, this study will suggest and emphasis that every language have its own rights which must be taken into account without any excuse. The study incorporates in-depth analysis of last 20 years language policies of Pakistan from critical perspective.

\subsection{Statement of problem}

Despite of numerous literature and researches in the context of language policy and planning in Pakistan, what seems to be under-researched is its possible association with the nation-building process in the context of Pakistan. As a qualitative research, the present article will investigate that to what extent the process of Pakistan's national identity construction has been influential on the successive governments' language policy decisions. To achieve this goal, the language policy documents are analyzed from Critical language policy perspective, in addition to collecting the views of those who are expert in language studies. Evaluating policies from the political and critical perspective unveil the hegemonic nature of these polices and their severe influence over their target population, on marginalized communities.

\subsection{Research Questions}

This study aims to answer following research questions:

1. What is the nature of the relationship between language policy making process and nation-state identity building process in Pakistan?

2. What are the consequences of nation-building process on other indigenous languages of Pakistan?

\section{Literature Review}

This section briefly highlights the studies on the topic of ethnicity, nation, nationalism, language policy and planning generally and present cursory overview of LLP related studies in the context of Pakistan. Ethnicity or ethnic group are not just a group of people sharing similar cultural characteristics and history, but they are the one who are self-aware of their discreteness among other groups. This idea of common origin and culture which strengthen their sense of groupness and community is not deliberately constructed but rather primordial (Smith, 1996, p.189). In case of 'Nation', it is a socially constructed modern phenomenon (May 2001), through state sponsored policies goaled at formation of a nation within state; 'nation-state' (Wright, 2000, p.3). Gellner (1994, p.286) defines nationalism, as a process of "striving to make culture and polity congruent, to endow a culture with its own political roof, and not more than one roof at that". He further added that although to define 'culture' is an ambiguous task, but it is inevitable that language is an important criterion of culture. As a common language is crucial for instilling the sense of belonging to a nation in order to construct a cohesive and unity society. Gellner (1994) regarded Nationalism as political concept, as it plays an important role in politization and culmination of nationalism that is essential in the creation of the state (Safran, 1999, p.77). Therefore, in the context of nationalism, language is perceived as an important political tool, which helps in shaping national identity, hence nation-state. Thus, language policy planning, national language planning particularly, is important in creating and maintaining national identity, nationalism and nation-state. The language policy refers to be government's deliberative planning efforts to affect or determine the status, corpus and acquisition of a language in a speech community (Cooper, 1989, Wright 2004). Most of the states, who got independence after World war 2, associate the concept of "Nation" with a shared common language, which is primarily used to promote and preserve nationalism (Anderson 1991; Simpson, 2007). Language serve to be crucial symbolic marker of a group or individual's identity, as it is used as a tool to integrate various groups into a single and common identity. After independence, the naïve states often adopt a common national/official language which would help them in nation-building process, in forming nation-states, in order to unify its citizens and promote socio-economic equality within its population 
(Simpson, 2007). Pakistan upon independence from British colonial rule with partition of sub-continent in 1947 , adopted a policy of promoting the Urdu language as the only national language of Pakistan in order to forge common Pakistani identity and promote national unity. Given the Pakistan's history and social reality, with its diverse multi-ethnic and multi-lingual population, its language policy is highly political and sensitive issue; only initiated by governments (Gill, 2005). With change in political structure, the language policies also vary. After independence, two language were dominant at that time: Bengali; spoken by $56 \%$ of the population and Urdu; constituting 3\% of total population. For which Mahboob (2002) quoted Muhammad Ali Jinnah's speech, “...it is for you, the people of this province, to decide what shall be the language of your province. But let make it clear to you that the State Language of Pakistan is going to be Urdu and no other language. Anyone who tries to mislead you is really the enemy of Pakistan.' This approach received severe reaction from Bengali people who were in majority, leading to repeated protests against Urdu as the only national language which eventually leads to the creation of Bangladesh.

In first education commission of Pakistan (1959) was issued after the first Marshal law 1958 in the era of General Ayub khan, who was pro-English and consider it as language of modernity. Mahboob (2002, p.21) also discussed that in Pakistan it was not possible to choose Urdu as national as well as official language of the country, due to Urdu's under-developed corpus. This created three language structure in Pakistan to maintain smooth running of government. Urdu was made the national language beside English being positioned as official language and the recognition of provincial language were left on provincial governments, without any compulsions or reinforcements from central governments. Pakistan was the first independent country who experienced dismemberment 1971 with the separation of East Pakistan into an autonomous country: Bangladesh. After the separation, the issue of national language declined as there was no competition to Urdu then. In the era of Zulfiqar Ali Bhutto, being a socialist leader, he also emphasized on the importance of the promotion of Urdu language in integrative symbol for nation formation. The 1973 Constitution formulated during Bhutto's government stated that:

Clause 1: The national language of Pakistan is Urdu and arrangements shall be made for its being used for official and other purposes within fifteen years from the commencing day.

Clause.2: Subject to clause (1) the English language may be used for official purposes until arrangements are made for its replacement by Urdu.

Bhutto's democratic government was overthrown by 3rd Marshal law imposed in 1977 in Pakistan's history by General Zia-ul-Haqq; who made drastic changes in language policies (Haque, 1993). General Zia holds strictly religious view regarding the administration of country. He introduced 'Islamization' policies in the country which accentuate Islam as religion of state and Urdu as language of the state. In his era, English medium school are advised to switch from English to Urdu or any other provincial language to be the medium of instruction which disadvantage minority languages. Government schools were emphasized to use Urdu as language of instruction from class 1, in addition to English from class 6 . This has also caused and boosted sectarian conflicts in country which had often leads to language movements in future, like; Sindhi language movement, Pashto movement and Punjabi language movement (Rahman, 1996). General Zia's government was been succeeded by Benazir Bhutto's government. The language policy in her reign offers the option to choose English as medium of instruction for all subjects and English should be introduced at primary level from class 1 rather than class 6 (Mahboob 2002, p.26). Later in General Pervaiz Musharraf's government English was promoted as being the language of modern world. He aims to boost the country's economy and foreign investments, for which English was considered as language of global market and important for the entry in international world. Pakistan is a multiethnic state, where resides several different ethnic groups having distinctive identities and languages of their own. Such identities have very long history of origin in this specific region. According to census of Pakistan (2017) based on population by mother tongue shows that $44 \%$ of its population speaks Punjabi language, 15\% speaks Pashto, 14\% speaks Sindhi, 10\% are Saraiki and 3\% speaks Balochi and $4 \%$ constitute the speakers of other languages, where Urdu is the language of $7.57 \%$ of the population. Rahman (2006) maintains that due to the unequal power structure of Pakistan, where only one group hold supremacy, the indigenous languages have lost its importance even for their native speakers because of lack of their instrumental value in society. The tension between state-sponsored language policy and population's emotional attachment with their identities have often leads to language riot during the course of the country's history (Rahman, 2002).

\section{Research Methodology}

This is a qualitative research study. Qualitative research approach involves the collection of data and in-depth analysis of it in order to attain insight into the subject of interest. The data analysis procedure involves the coding of data from which emerges the themes and providence of their description. According of Ian Dev (1993), the term 'qualitative research' has being fashionable as it refers to any research method other than survey. Qualitative research includes semi or un-structured interviews, (participants or non-participant) observation, group interviewing and collection of the documentary materials etc. 


\subsection{Data collection and analysis}

The data used for this research study are obtained from two sources: National Education policy documents (documents published in last 20 years) and semi-structured interviews. A thorough investigation of language policies in the NEP documents is done in order to reflect upon the linguistics status planning in Pakistan and look in for the present position of indigenous languages in language policies. Additionally, the interviews were conducted from the experts in the field of Linguistics. Interviews are taken an observatory data which are not analyzed by the researcher, but it aids in gaining insight into the phenomenon under study. While, National policy documents were analyzed using content analysis. Content analysis is useful in dividing descriptive data in codes and categorize them into themes (Creswell, 2008).

\subsection{Participants and sampling process}

The study opted purposive sampling to select the participants for this study. Purposive sampling aids the researcher in recruiting the participants based on their experience and knowledge which serve the purpose (Berg, 2001). Five participants were selected for in-depth semi-structured interviews. The participants were selected based on their knowledge and research experience in the field of language studies. Those people who are professor or assistant professors of linguistic at university level and having a good expertise in research field of sociolinguistic in general and language policy and planning in Pakistan in particular.

\section{Findings and discussion}

The results of this study present the analysis of National Education policy documents, which is reiterate by data collected from interviews. It is narrated in National Education Policy (2017) that the goal of education is to "Promote and foster ideology of Pakistan creating a sense of Pakistani nationhood on the principles of the founder of Pakistan i.e. Unity, Faith and Discipline" (NEP 2017, p.10). Similarly, the language policies in Pakistan, language-in-education policies in particular, are fundamental in nation building process. Given the social and political reality of Pakistan, with its multiethnic and multilingual nature of the society, the country has a number of indigenous ethnic groups historically originated and dwelled on this particular geography. For such pluralistic countries in all aspects, language policy become very crucial as well as complex task (Zawawi, 2005). The successive government have explicitly used language policies to unit this multilingual population under a commonly shared national identity. National Education policy $(2009$, p.11) clearly states that, "English is an international language, and important for competition in a globalized world order. Urdu is our national language that connects people all across Pakistan and is a symbol of national cohesion and integration. In addition, there are mother tongues/local vernaculars in the country that are markers of ethnic and cultural richness and diversity." According to this policy, Urdu language constitute the soul of Pakistani nationalism and national-identity. The Urdu language was made to be national language through objective resolution 1947, and English was positioned as official language which mean second most important language vis-à-vis Urdu in state's affairs and public domain (Asmah, 1992, p.24). Pakistan have adopted monolingual language-in-nation policy model of nationbuilding, where only one language: Urdu is associated with the state-sponsored national-identity and there is no space for other vernacular languages of the country. Urdu, to be promoted as national language, is made to be perceived as an 'ethnically neutral' language somehow and symbolically language of Muslims (Sikandar, 2017).

The Islam serves to be the central component of Pakistan's foundational ideology, and sole reason for the struggle of Muslims of sub-continent for independence. Urdu was symbolically and ideologically associated with the idea of Muslimness hence with Islam. In this regard, one of the linguists interviewed said that, "there is no literal connection between language and religions, if there is pose to be a connection than it would be deliberately socially constructed". In the struggle for independence by Muslims of sub-continent, who define themselves to be in contradiction to Hindu identity, Urdu was extensively used as common medium of communication between them. After the independence, As the newly independent state based its ideology on the principles and values of Islam, all the symbolic associations with it was given prominence, be that language. Urdu being regarded as language of Muslims, having a separate identity which become national-identity, which is further reinforced by the state. The National Education policy (2017, p.24) states that, "Islamiyah will be introduced as compulsory subject from class III to Intermediate classes extending up to graduation in all general and professional institutions as in the past. For Early Childhood Education (ECE) and classes I to II, it will be integrated in other subjects, including Urdu text-book". This shows the deliberate attempt of for the association of Urdu with Islam, by opting Urdu as medium for Islamic studies. As there was no space for any religion other than Islam in the conception of Pakistani nation, same is the case with the indigenous languages of Pakistan, where only prescribed national language is given prominence.

As said by Mustafa (2011, p.2), Pakistan's language-in-education policy is determined by political expediency, economic injustice and most importantly class prejudice, rather than proper scientific research. The choice of Urdu as national language was also based on extra-linguistic factors, rather than on linguistic rationalization. Such monolingual and discriminatory policies are result power involved in determining the status 
of language in a state. As Bourdieu (1991, cited in Tamim, 2013) states that language policy is extensively used to reinforce the dominance of the privilege group through the mediation of education institutes. Language policy is not only the reflection but also the result of power structure in the society. This is the case with Urdu, Wee (2011, p.26) called it as 'unavoidability of language'. This term refers to the fact that if the state opts a language to be used in power domains, so it necessarily privileges the speakers of that language. In case of Urdu, it is the Punjabi ruling elite class who identify themselves with Urdu language and are the power operators of the state. They even tend to replace Punjabi with Urdu as their first language and do not encourage Punjabi's acquisition by the new generation. One of the participants also commented that, "the one who is powerful the language they speak and identify themselves with also become powerful, and the rest of the population speaks that powerful language but not the vice versa". Same is the case with Urdu which is the preferred language of powerful Punjabi elite. Another participant commenting on the issue with Punjabi language said that, "there is the deliberate stigmatization of Punjabi language and similarly other indigenous languages, by not including them in power domains like education, administration, media and bureaucracy. This create negative attitude of the people towards their mother-tongue, that they are not ready/motivated to learn them, who are drawn towards more powerful and useful languages".

Such assimilationist and hegemonic policies require linguistic homogenization as essential criterion for its population in signifying themselves with Pakistani national identity (Rahman, 1996), which sideline or marginalize the other indigenous languages spoken in Pakistan. This inundate monolingual conception regarding nationalidentity perceive the promotion and usage of languages, other than official/national language, as a threat to national integration, which problematize the existing of these indigenous languages in Pakistani society. Any attempt of claiming the basic right of representation by their cultural identity is regarded as anti-state rebellious act. Such claims are often made by nationalist groups who define themselves as groups with historically distinctive ethnic identity having their own culture, tradition and languages. Their demand of use and recognition of their mother tongue are not portrayed as emotionally charged policy with overtly symbolic identity related agenda but is looked down as movements with hidden separatist agenda.

As Heugh $(2003$, p.4) highlighted that despite of creative political maneuvering in Constitution and language policy documents concerning the issues of indigenous languages, its detailed investigation can reflect the inconsistencies and omissions which shows the nature of government's attitude towards it. Analyzing the discourse of official documents shows that there is no mention of the names of any indigenous languages in the policy. The terms like, 'minority languages', vernaculars' or mere 'other language' are used to refer to the indigenous languages of Pakistan. The word 'minority' is used as euphemism to signifier of under-represented and powerless languages. The text does not even include the names of 5 main language spoken by majority of population, they are also categorized under the term of minority languages. Additionally, the policy documents do not include any serious discussion concerning the promotion and preservation of these languages. It does not include any practical measures for their promotion, acquisition and teaching for the population. Such types of discussions are limited to the topic of Urdu and English languages. The marginalization of indigenous languages is further worsened by the presence of English in power domains. Its superiority works to reinforce the socio-economic division in Pakistani society. Nation education policies $(2009,2017)$ debates upon the choice for medium of instruction where there seem to be a tie between English and Urdu. English is made to be the medium of instruction in private schools and Urdu in public sector. The access to English perceived as economic advantage and Urdu's competence is necessary for national communication and identification, while the other languages does not hold any instrumental value, which make them useless to be acquired.

\section{Conclusion}

From this study, it become evident that the issue of language cannot be studied in isolation from power structure. The power politics often have put considerable influences on the decisions regarding language policy of Pakistan. Since the independence of Pakistan in 1947, Urdu was always given the most prominent position in case of Pakistani national identity. Resultantly, other vernacular languages of Pakistan who were given utilitarian value in pre-partition era have lost their value after the independence of Pakistan. The language policy put more emphasis on the use of Urdu in power domains and in education domain particularly, moreover, attaching utilitarian value to it, which makes it desired and wanted in Pakistan hence making its acquisition compulsory. Pakistan being a multilingual country, giving more importance to one or two languages proves to be problem for other indigenous languages. Even the seven major language in Pakistan (spoken by considerable majority of population) are not given any official recognition. Whereas the other indigenous language spoken by minority population are at grave disadvantage. Imposing one language as the 'language of nation' over people speaking different languages is hegemonic and discriminatory. The government of Pakistan need to devise a feasible language policy which should incorporate all the local languages which must be given due placement and recognition in local as well as education context. Every individual must be provided the right to get at least the basic education in his/her mother tongue as medium of instruction and represent themselves with their native language in public sphere. This is the only way we can preserve and promote our multilingual asset and all the vernacular languages who have old history of more 
than thousand years in this geographical region.

\section{References}

Anderson, B. R. O. G. (1991). Imagined communities: Reflections on the origin and spread of nationalism. London: Verso

Asmah, H. O. (1992). The linguistic scenery in Malaysia. Selangor: Dewan Bahasa dan Pustaka.

Berg, B. L. (2001). Qualitative research methods for the social sciences (6th ed.). Boston: Allyn and Bacon.

Cooper, R. L. (1989). Language Planning and Social Change. Cambridge University Press.

Creswell, J. W. (2008). Qualitative Inquiry \& Research Design (3rd ed.). Sage Publication.

Dey, I. (1993). Qualitative Data Analysis. London and New York: Routledge Taylor and Francis Group. https://doi.org/10.4324/9780203412497

Errington (2008). Linguistics in colonial world: A story of language, meaning and power. Blackwell Publishing.

Gellner, E. (1994). Nations and nationalism. In R. K. Betts (Ed.), Conflict after the Cold War (pp. 280-292). New York: Macmillan Publishing Company.

Gill, S. K. (2005). Language policy in Malaysia. Language Policy, 4, 241-260.

Government of Pakistan (10 April 1973). The Constitution of the Islamic Republic of Pakistan 1973. Consolidated version of 2015, modified upto 21st Amendment. [online] Available: https://www.refworld.org/docid/47558c422.html [accessed 02 October 2020]

Government of Pakistan, Ministry of Education, National Education Policy 2009 (Revised August 01, 2009). Islamabad: Government of Pakistan, Ministry of Education, 2009.

Government of Pakistan, Ministry of Federal Education and Professional Training, National Education Policy (2017). Islamabad: Government of Pakistan, Ministry of Federal Education and Professional Training, 2017

Government of Pakistan, Pakistan Bureau of Statistics, Population by Mother Tongue (2017) [online] Available: http://www.pbs.gov.pk/content/population-mother-tongue

Haque, A. (1993). The Position and Status of English in Pakistan. In 'The English Language in Pakistan.'

Heugh, K. (2003) Language policy and democracy in South Africa: The prospects of equality within rights-based policy and planning. Unpublished PhD Thesis: Centre for Research on Bilingualism, Stockholm University.

Kaur, P., \& Shapii, A. (2018). Language and Nationalism in Malaysia: A Language Policy Perspective. International Journal of Law, Government and Communication, 3(7), 1-10.

Kramsch, C. (2009). Language and Culture. London: Oxford University Press

Mahboob, A. (2002). No English, No Future: Language Policy in Pakistan in Political Independence with linguistic servitude. In S. Obeng \& B. Hartford (Eds.), The Politics about languages in the Developing world (pp. 1539). New York: Nova Science Publishers.

Manan, S. A., Dumanig, F. P., \& David, M. K. (2017). The English-medium fever in Pakistan: Analyzing policy, perceptions and practices through additive bi/multilingual education lens. International Journal of Bilingual Education and Bilingualism, 20(6), 736-752. https://doi.org/10.1080/13670050.2015.1080659

May, S. (2001). Language and Minority Rights: Ethnicity, Nationalism and the Politics of Language. Harlow: Pearson Education.

Mustafa, Z. (2011). Tyranny of language in education, the problems and its solutions. Karachi: Ushba Publishing International.

Pathan, H. (2012). A longitudinal Study of Pakistani University Students' Motivation for Learning English. Unpublished PhD Thesis. [online] Available: http://theses.gla.ac.uk/4534/1/2012PathanPhD.pdf

Philipson, R. (1992). Linguistic Imperialism: Oxford University Press.

Rahman, T. (1996). Language \& Politics in Pakistan. Oxford University Press: Karachi.

Rahman, T. (2002). Language, Ideology \& Power: Language Learning among the Muslims of Pakistan and North India. Oxford University Press: Karachi.

Rahman, T. (2006) "The Urdu-English Controversy in Pakistan.” Modern Asian Studies.

Rahman, T. (2007). The role of English in Pakistan with special reference to tolerance and militancy. In A. Tsui \& J. W. Tollefson (Eds.), Language policy, culture and identity in Asian contexts (pp. 219-239). Mahwah, NJ: Lawrence Erlbaum.

Rahman, T. (2010). Language policy, identity, and religion: Aspects of the civilization of the Muslims of Pakistan and North India (2nd ed.). Islamabad: National Institute of Pakistan Studies, Quaid-i-Azam University.

Safran, W. (1999). Nationalism. In J. A. Fishman (Ed.), Handbook of language and ethnic identity (pp. 77-93). Oxford, New York: Oxford University Press.

Shah, S. W. A., \& Pathan, H. (2016). Representation of Western Culture in O' level English Language Textbooks. English Language Forum (ELF), 18.

Shah, S. W. A., et al. (2018) Language Policy and Its Consequences on Sindhi Language Teaching in Sindh, Pakistan. Published in International Journal of English Linguistics; Vol. 8, No. 5, pp. 135-141; Published by Canadian Center of Science and Education. https://doi.org/10.5539/ijel.v8n5p135 
Sikandar. A. (2017) Language policy planning in Pakistan: A Review. Published in Pakistan Business Review, Vol 19, No 1, pp. 267 - 272. http://dx.doi.org/10.22555/pbr.v19i1.1264

Simpson, A. (2007). Language and national identity in Asia: A thematic introduction. In A. Simpson (Ed.), Language and national identity in Asia (pp. 1 - 30). New York: Oxford University Press.

Smith, A. D. (1996b). Chosen Peoples. In: J. Hutchinson \& A. D. Smith. Ethnicity. Oxford: Oxford University Press, pp. 189-197.

Spolsky, B. (2004). Language Policy. Cambridge: Cambridge University Press.

Tamim, T. (2013) The Politics of Language in Education: Issues of access, social participation and inequality in the multilingual context of Pakistan: Published in British Education Research Journal, Vol 40, Issue 2, pp: 280-299. DOI: http://doi.org/10.1002/berj.3041

Tong, H. K., \& Cheung, L. H. (2011). Cultural identity and language: A proposed framework for cultural globalization and glocalization. Journal of Multilingual and Multicultural Development, 32(1), 55-69.

Wee, L. (2011). Language without rights. Oxford studies in Sociolinguistic. New York: Oxford University press.

Whitley, W. (1983). Sociolinguistic Surveys at the National Level. In C. Kennedy (Ed.), Language Planning and Language Education (pp. 68-79). London: George Allen \& Unwin.

Wright, S. (2000). Community and Communication: The Role of Language In Nation-state Building and European Integration. Clevedon: Multilingual Matters.

Wright, S. (2004). Language Policy and Language Planning: From Nationalism to Globalization. Palgrave Macmillan.

Zawawi, I. (2005). Globalization and national identity: Managing ethnicity and cultural pluralism in Malaysia. [online]

Available: http://www.apcss.org/Publications/Edited\%20Volumes/GrothGovernance files/Pub Growth\%20Governan ce/Pub_Growth\%20\%20Governance\%20ch9.pdf. (accessed November 2020) 